\title{
Lean Management: A Review of Literature
}

\author{
Oloyede Raheem LAWAL ${ }^{\star}$, Ayobami Folarin ELEGUNDE ${ }^{\star}$
}

\begin{tabular}{l}
\hline \multicolumn{1}{c}{ A R T I C L E I N F O } \\
\hline Article history: \\
Accepted June 2020 \\
Available online August 2020 \\
\hline JEL Classification \\
M10, M11 \\
Keywords: \\
Just-In-Time (JIT), Lean \\
Management, Manufacturing and \\
Service Industry
\end{tabular}

\section{Introduction}

Managing organisations for appropriate results have undergone a lot of changes over time. The quest for improvement over time gave birth to scientific management, classical, behavioural, humanistic, contingency method over time. Yet the expected efficiency is yet to be reached. Continuous change in the management style also led to knowledge management. Today, the issue of management style that will bring expected result at a low cost and wastage gave birth to what is called lean management (LM). LM is an approach to running an organization that supports the concept of continuous improvement, a long-time approach to work that systematically improve organizational efficiency and it quality (Saurah \& Nishi, 2016). Lean management is an important tool used by manufacturing and non-manufacturing industries in the global market to eliminate organisational waste of money by identifying each step in a business process and then revising or cutting out steps that do not create values. Industries have adopted lean management practice to produce goods in order to compete favorably and survive in the business world.

Sundareshan, Swamy and Nanjundeswara (2015) posited that business environment has been increasingly becoming volatile. As such, the application of LM by organistion's managers help industry to gain competitive advantage in the global market. Shah and Ward (2003) define LM as "a multi-dimensional approach that encompasses a wide variety of management practices (such as Just-In-Time (JIT), Kanban, Kaizen, Value Stream Mapping (VSM), 5S and Jidoka and so on) which have proven useful to respond rapidly to customer's needs towards cost reduction, provide products of higher quality and fast delivery in a shorter lead time. Lean management practice and techniques have been widely used by manufacturing industries to gain a competitive advantage over rivals (Garza-Reyes, Oraifige, Soriano-Meter, Forrester \& Harmanto, 2012). In essence, lean management practice allow companies to become more competitive and enhance the likehood of survival (Christian, 2010).

This concept of lean was developed by the Japanese in 1950s to stabilize and standardize the work processes so that the critical problems become clearly visible and the workforce develops critical thinking in order to solve identified problems in an organisation and improve overall work flow. Lean management practice have been efficiently utilized in manufacturing industries for the past two decades in Japan (Alsmadi, Almani \& Jerisat, 2012). According to Womack, Jones and Roos (1990) lean management practice originated in Japan and it has proven effective in helping industries to improve their organisational performance (Mintz, 2003). The implementation of lean management has been very much successful in the manufacturing sector. Due to its high efficacy, it has been transferred to other sectors in Japan (Hillier \& Clayton, 2016).

${ }^{\star},{ }^{\star \star}$ Lagos State University, Nigeria. E-mail addresses: oloyederaheem@gmail.com (O. R. Lawal), ayobami207@gmail.com (A. F. Elegunde) 
Womack, et al (1990) in their book "The machine that changed the world" clearly outlined the philosophy, which explained the evolution of lean manufacturing practices in the automobile industry in Japan. "Lean" manufacturing practice derived mainly from the Toyota Production System in the 1980s and it has been seen as a symbol of efficiency and optimal performance (Saurabh \& Nishi, 2016). Lean manufacturing process offered more cost advantage over the mass production approaches that are traditionally practiced. The advent of lean management helps organisations in reducing cost cycle time and eliminating all waste through continuous improvement.

\section{Statement of the problem}

Many organisations are facing different challenges due to stiff competition in their respective fields due to several factors such as technology change, change in taste and fashion through the advent of globalization (Begam, Swamnynathan \& Sekkizhar, 2013). The negative impact of this globalization has led to low performance which by extension had depleted customers satisfaction level in these industries. Shah, Ganji and Alec (2017), related the low performance level occasioned by globalization to poor delivery of products to target consumers.

Nitin, Desmukh and Garg (2010) posited that one of the simplest methods for addressing the issue of customers' satisfaction is to apply the method of LM. As a result, manufacturing industry and other sectors may achieve its set objectives through the adoption of lean management practice to eradicate poor delivery system by eliminating waste and simultaneously creating value for service delivery to target consumers and by extension to enhance organisational effectiveness and efficiency. Lean management has attracted vast interest from both academics and practitioners. The most technical aspects of lean management have been widely discussed and it has become a universal production method around the world such as Toyota and other companies have successfully implemented it. Though, lean management started in the automotive industry, it has been applied in other disciplines successfully as well (Mohd, Raneez \& Inamdar, 2010). Due to heightened challenges from global competitors, lean management has become a production method for many organisations to pursue.

Moreso, research on assessment of lean management implementations and its performance in the service industry is limited (Vignesh, Suresh \& Aramvalarthan, 2016). The way and manner in which lean management is implemented in service industries differs from manufacturing.

From scholar's perspective, Olatunji (2018); Daferighe, James and Offiong (2018) traced collapse of firms to inability to develop a technique such as lean management practice that can support organization to minimize cost and wastage. This form the basis of this study which reviews the conceptual underpinnings that could expose it's to the world business environment.

\section{Objectives of the study}

The objective of this study is to do a review of literature on the subject matter. This study explores the different positions, the pros and cons and the issues relating to the adoption of LMP in business organisations and the way out in applying this concept. It also aims at identifying the best method to use or employ in achieving minimum cost, avoiding wastages and achieving maximum profit.

\section{Lean Management Concept and its features}

Lean management concentrates on professional training and shaping the staff's attitude as well as maintaining positive public relation (Lichtarski, 1997). According to Shah et al (2017) lean management is simply all about operating the most proficient as well as effective organization possible, with a minimal cost and zero waste and still meeting the demand of customer's request. Currently, LM has been proven by recognisable scientists and practitioners as one of the most useful management techniques that organization can be used to minimize or eradicate unnecessary wastages (Womack \& Jones, 2008).

Womack and Jones (2008) stated that for lean management practice to work effectively in any organization, it is advised that every manager of a company should give thought to the following: Good atmosphere in the workplace, Setting the objectives, Communication, Proper Motivation, Wasting human potential, Development of employees, and Leadership. Hence, it has shown that lean management practice requires careful application in human resource management has mentioned above. For this reason, in order to make an organisation achieved its set objectives, the aforementioned need to put into consideration by organisation's management.

\section{Principles of Lean Management Practice in Manufacturing and Service Industries}

Womack and Jones (1996) pointed out from a precisely functional approach and states the way in which LM can be understood and five principles of the system were pointed out, these are: (i). To defined value for each product (Womack \& Jones, 1996). (ii). Eradicating all unnecessary steps in every value stream. (iii). Making value flow. (iv). Knowing that the customer pulls all activities (Womack \& Jones, 1996). (v). The constant pursuit of perfection. Womanck and Jones (1996) opined that search for waste and wasteful processes can help improve the quality of products and assist in the search for perfection, just as efforts made 
toward continuous improvement will help identify waste. All these principles help the product (value) flow more smoothly through the plant.

The major guiding principles of lean management is the removal of various forms of waste from the manufacturing process. Meanwhile, elimination of waste is a primary goal of any lean system. Lean declares war on waste. Daferighe et al (2018) posited that waste is anything that does not have value or does not add value whereby the customer will not pay for. Waste can be in form of unnecessary output, input, or processing and it may also be a material, stocks, equipment, facilities, man-hours, utilities, documents expenses, motion, and other activities that do not add value.

For any organization to stop waste, firstly it must recognize waste, identify who is responsible and finally appreciate its size and magnitude. Waste that is not seen cannot be eliminated. According to Mohd (2017), a lean management practice in manufacturing industries classified wastes into 7 types and they are (i) over production waste (ii) Processing waste, (iii) Transport waste (iv) Waiting waste (v) Inventory waste (vi) Motion waste, and (vii) Defect.

\section{Elements of Lean Management Practice}

Several scholars suggested that there are many lean management tools or techniques which have been used to improve customers' satisfactions through elimination of unnecessary wastes (Rene,2018; Shah et al, 2017; Sundareshan, Swamy \& Nanjundeswara, 2015). The widely used lean management technique that organisation may use to improve their services are: JIT, VSM, Jidoka, 5S, Heijunka, Kaizen and Kanban.

\section{A Comparative Analysis of Lean Management Tools}

\section{Table 1: Showing comparative analysis of lean management tools}

\begin{tabular}{|c|c|c|c|c|}
\hline $\mathrm{S} / \mathrm{N}$ & $\begin{array}{c}\text { Tools/ } \\
\text { Technique }\end{array}$ & Description/Distinct Features & Outcome & Application \\
\hline 1 & Heijunka & $\begin{array}{l}\text { A kind of production } \\
\text { scheduling that meant for } \\
\text { producing smaller batches by } \\
\text { sequencing product variants } \\
\text { within the same process. }\end{array}$ & $\begin{array}{l}\text { Reduces lead time (since } \\
\text { each product is } \\
\text { manufactured } \\
\text { frequently) and inventory } \\
\text { (since batches are } \\
\text { smaller). }\end{array}$ & $\begin{array}{l}\text { Imam, Muhammad, Hizka \& Toto (2018) they } \\
\text { observed that company's current production } \\
\text { system has not been in balance because } \\
\text { production demand and production planning } \\
\text { always change. Heijunka principle was applied to } \\
\text { fundamentally remove the mura, muri and muda. } \\
\text { The findings process and design the TPS based on } \\
\text { the principle of heijunka to improve the } \\
\text { productivity of human labour. }\end{array}$ \\
\hline 2 & $5 S$ & $\begin{array}{l}\text { Sort, set in order, Shine, } \\
\text { Standandise and Sustain. }\end{array}$ & $\begin{array}{l}\text { It eradicates waste that } \\
\text { comes from a poorly } \\
\text { organised environment ( } \\
\text { e.g delaying work by } \\
\text { looking for appropriate } \\
\text { tool). }\end{array}$ & $\begin{array}{l}\text { Fanny, Y. F (2014) pointed out the information } \\
\text { about } 5 \text { S lean ways to implement it in health care } \\
\text { setting. Results shown that } 5 \mathrm{~S} \text { can be applied to } \\
\text { health care services with beneficial effects. }\end{array}$ \\
\hline 3 & Jidoka & $\begin{array}{l}\text { Design equipment to partially } \\
\text { automate the plant during } \\
\text { manufacturing process and to } \\
\text { automatically stop the plant } \\
\text { immediately when defects are } \\
\text { detected. It is much less } \\
\text { expensive than the full } \\
\text { automation }\end{array}$ & $\begin{array}{l}\text { Workers can frequently } \\
\text { monitor different stations } \\
\text { (reducing labour costs) } \\
\text { and many problems can } \\
\text { be detected immediately } \\
\text { (improving quality). }\end{array}$ & $\begin{array}{l}\text { Muhmut, Murat, Mehmet, Ozdul \& Ertugrul (2019) } \\
\text { viewed that business have had to use sustainable } \\
\text { flexible production methods and techniques } \\
\text { which quality focused, cost-effective and the least } \\
\text { wasteful in order to meet customer demand } \\
\text { expection. Successful results were obtained } \\
\text { regarding the applied jidoka and SMED } \\
\text { techniques. }\end{array}$ \\
\hline 4 & VSM & $\begin{array}{l}\text { A tool used to visually map the } \\
\text { flow of production and it also } \\
\text { shows the current and future } \\
\text { state of processes in way that } \\
\text { highlights opportunities for } \\
\text { improvement. }\end{array}$ & $\begin{array}{l}\text { Exposes waste in the } \\
\text { current processes and } \\
\text { provides a roadmap to } \\
\text { improve the future state. }\end{array}$ & $\begin{array}{l}\text { Gbedebo, Peter \& Tiamiyu (2018) evaluated the } \\
\text { adoption of lean technique for waste elimination } \\
\text { through VSM. Series of VSP techniques were used } \\
\text { such as } 5 \mathrm{~s} \text {, Kanban pull system, supermarket pull } \\
\text { system, SMED kaizen idea sheet. The results } \\
\text { showed that production lead time was massively } \\
\text { reduced from } 34.4 \text { hours to } 5.04 \text { hours with a } \\
85.3 \% \text { awste reduction. }\end{array}$ \\
\hline 5 & JIT & $\begin{array}{l}\text { Pull parts through } \\
\text { manufacturing based on } \\
\text { customer request instead of } \\
\text { pushing parts through } \\
\text { manufacturing based on } \\
\text { projected request. }\end{array}$ & $\begin{array}{l}\text { Highly effective in } \\
\text { reducing inventory levels. } \\
\text { improves cash flow and } \\
\text { reduces } \\
\text { requirements. }\end{array}$ & $\begin{array}{l}\text { Singh, Rajdeep, Jaskanwal \& Sukhvir (2013) the } \\
\text { study revealed that JIT play an importunate role } \\
\text { in better functioning of supply chain management. } \\
\text { The lean manufacturing principle used are: JIT } \\
\text { inventory, JIT production, JIT human resource, JIT } \\
\text { quality and JIT supply relation. }\end{array}$ \\
\hline 6 & Kaizen & $\begin{array}{l}\text { A strategy where employees } \\
\text { work together proactively to } \\
\text { achieve regular, incremental } \\
\text { improvements in the } \\
\text { production process. }\end{array}$ & $\begin{array}{l}\text { Combines the collective } \\
\text { talents of a company to } \\
\text { create an engine for } \\
\text { continually eliminating } \\
\text { waste from production } \\
\text { processes. }\end{array}$ & $\begin{array}{l}\text { Omotayo \& Kulatung (2017) they demonstrated } \\
\text { of how kaizen which is continuous improvement } \\
\text { in thework place can be implemented using } \\
\text { busiess process modelling and notation. The } \\
\text { findings of this study focused on the perception } \\
\text { towards change, post-project reviews, openness } \\
\text { to new ideas and innovation. }\end{array}$ \\
\hline
\end{tabular}




\begin{tabular}{|c|c|c|c|c|}
\hline $\mathrm{S} / \mathrm{N}$ & $\begin{array}{c}\text { Tools/ } \\
\text { Technique }\end{array}$ & Description/Distinct Features & Outcome & Application \\
\hline 7 & Kanban & $\begin{array}{l}\text { Method of controlling the flow } \\
\text { of product within the } \\
\text { organisation and with outside } \\
\text { suppliers and customers. }\end{array}$ & $\begin{array}{l}\text { Elimination of waste from } \\
\text { inventory and over } \\
\text { production. }\end{array}$ & $\begin{array}{l}\text { Muhammad, Jouni \& Markku (2013) research was } \\
\text { conducted in order to analyze the current trend of } \\
\text { Kanban usage in software development and to } \\
\text { identify the benefits and involved challenges. The } \\
\text { findings of their work are intended for helping } \\
\text { researchers and practitioners to gain the } \\
\text { application of Kanban usage in terms of } \\
\text { improving lead time, quality, communication and } \\
\text { coordination, increase consistency of delivery and } \\
\text { decreased customers reported defects. }\end{array}$ \\
\hline
\end{tabular}

Based on the comparison of lean management tools, it has shown that all these methods are useful for organisations to reduce waste, increase efficiency and deliver more value to customers. In the study of Ioannis, Garza-Reyes \& Kumar (2018) they concluded that lean approach has helped management to improve their operations and process. They investigated the impact of five essential lean methods i.e JIT, Jidoka, Kaizen, TPM and VSM. Using a linear regression analysis modelled. In addition, structural Equation Modelling (SEM) was used to cross verify the findings of the regression and correlation analyses. Meanwhile, the results indicate that JIT and Jidoka have the strongest significance on operational performance while others seems to have a lesser effect.

In conclusion, the most preferred method that could be used by organisation to reduce waste and improve efficiency is JIT. However, these method (JIT) relies mainly on lean technique for continuous flow and standardise work.

\section{Theoretical Review}

Production theory is adopted in this study. Production theory is the study of production, or the economic process of producing outputs from the inputs. Production uses resources to create a good or service that are suitable for use or exchange in a market economy. According to Koskela (2000) production theory previously prevailed in the West as a transformation perspective. Whereby, production is seen as a set of resource consuming transformation activities (cost centers) that should be optimized in terms of input or output. It is assumed within this perspective, that the entire transformation process can be subdivided into sub-processes which are also transformation activities that determine the overall cost of an item. i.e. subprocesses are considered to be independent.

Specifically, Koskela (2000) characterized Japanese manufacturing industry embedding as a flow perspective. In this perspective, time, not only as a dimension for coordination, but also as a valuable resource, is introduced into production theory. The notion of time as a resource allows management to see production as a coordinated flow of materials (level 1 in a production theory). It establishing queuing analysis as the set of governing laws (level 2 in a production theory). These laws establish the link between variability and weakened performance in terms of work-in-process (WIP) levels, lead times, variable process times, and less than optimal capacity utilization (Hopp \& Spearman, 2000). Hopp and Spearman (2000), opined that lean production is aimed at minimizing the cost of buffering variability which can be achieved by a combination of intelligent buffer switching, use of flexible resources, and variability reduction (level 3 in a production theory). Understanding these fundamental design, control and improvement principles is a wide range of LMP that can be argued for theoretically instead of dogmatically. Production theory is the theory that focuses on the transformation aspect, which is the key of an organisation for successful implementation of lean management practice during the production process.

\section{Gaps in Literature}

Table 2. Showing study gaps

\begin{tabular}{|c|c|c|c|c|c|}
\hline $\mathbf{S} / \mathbf{N}$ & AUTHOR(S) \& TITLE & $\begin{array}{l}\text { OBJECTIVES AND } \\
\text { SCOPE }\end{array}$ & METHODS & FINDINGS & GAP(S) IDENTIFIED \\
\hline 1. & $\begin{array}{l}\text { Eswaramoorthi, M, } \\
\text { Kathiresan.G.R., Prasad, } \\
\text { P.S.S \& Mohanram.P.V. } \\
(2011) . \text { A Survey on } \\
\text { lean practices in indian } \\
\text { machine tool industries. }\end{array}$ & $\begin{array}{l}\text { Examine the degree } \\
\text { to which the concept } \\
\text { of lean manufacturing } \\
\text { is put into practice } \\
\text { within } \\
\text { machine Indian } \\
\text { industries. }\end{array}$ & $\begin{array}{l}\text { Statistical } \\
\text { Package for } \\
\text { Social Science } \\
\text { (SPSS) } 15.0\end{array}$ & $\begin{array}{l}\text { The status of lean } \\
\text { implementation in the } \\
\text { machine tool sector is } \\
\text { still in infant stage. }\end{array}$ & $\begin{array}{l}\text { Ignores the appropriate } \\
\text { usage of lean tools which } \\
\text { Indian manufacturing } \\
\text { can be used to achieved } \\
\text { its organisational } \\
\text { performance. }\end{array}$ \\
\hline 2. & $\begin{array}{l}\text { Dinitris. F \& Theophilus. } \\
\text { F. (2011). Implementing } \\
\text { lean thinking paradigm } \\
\text { practices in medical set } \\
\text { up. }\end{array}$ & $\begin{array}{l}\text { Evaluate the } \\
\text { possibility of using } \\
\text { lean principle as a } \\
\text { continuous } \\
\text { improvement tool in } \\
\end{array}$ & & $\begin{array}{l}\text { Wall of } \\
\text { departmentalization } \\
\text { within the service points } \\
\text { that made the customers } \\
\text { not to be the center of }\end{array}$ & $\begin{array}{l}\text { Focuses on antenatal } \\
\text { patient while other } \\
\text { critical areas in the } \\
\text { hospital that needed } \\
\text { urgent attentionn was }\end{array}$ \\
\hline
\end{tabular}




\begin{tabular}{|c|c|c|c|c|c|}
\hline $\mathbf{S} / \mathbf{N}$ & AUTHOR(S) \& TITLE & $\begin{array}{l}\text { OBJECTIVES AND } \\
\text { SCOPE }\end{array}$ & METHODS & FINDINGS & GAP(S) IDENTIFIED \\
\hline & & $\begin{array}{l}\text { the medical set-up. } \\
\text { Three major hospitals } \\
\text { were used in Abuja, } \\
\text { Nigeria. }\end{array}$ & & $\begin{array}{l}\text { attraction rather the } \\
\text { interest of each units. }\end{array}$ & ignored. \\
\hline 3. & $\begin{array}{l}\text { Onyeizugbe, C. U \& Ike, } \\
\text { F. O. (2016). Lean } \\
\text { Production: A Frontier } \\
\text { for Improving } \\
\text { Performance of Oil and } \\
\text { Gas Companies in } \\
\text { Nigeria. }\end{array}$ & $\begin{array}{l}\text { Ascertain how lean } \\
\text { production affects } \\
\text { performance of oil } \\
\text { companies. Study is } \\
\text { limited to three } \\
\text { selected oil and gas } \\
\text { companies in Nigeria. }\end{array}$ & $\begin{array}{l}\text { Pearson Product } \\
\text { Moment } \\
\text { Corrolation was } \\
\text { used }\end{array}$ & 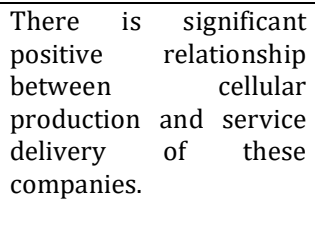 & $\begin{array}{l}\text { The study looks at } \\
\text { cellular production and } \\
\text { service delivery without } \\
\text { considering other lean } \\
\text { tools. }\end{array}$ \\
\hline 4 & $\begin{array}{l}\text { Onwughalu, O.O., Okeke. } \\
\text { K.E \& Henry-Chibor. E. } \\
\text { (2017) Lean Production } \\
\text { and its effect in } \\
\text { Organisations: A study } \\
\text { of selected } \\
\text { manufacturing firms in } \\
\text { Nigeria. }\end{array}$ & $\begin{array}{l}\text { Examined the effect } \\
\text { of lean production } \\
\text { among selected } \\
\text { manufacturing } \\
\text { organisation in Port } \\
\text { Harcourt. } \\
\text { selected Five } \\
\text { manufacturing firms. }\end{array}$ & $\begin{array}{l}\text { Statistical } \\
\text { Package for } \\
\text { Social Science } \\
\text { (SPSS) was used. }\end{array}$ & $\begin{array}{l}\text { Lean practices adopted } \\
\text { had positive relationship } \\
\text { in minimising variations } \\
\text { that associated with } \\
\text { suppliers, processing } \\
\text { time and demand. }\end{array}$ & $\begin{array}{l}\text { The domain of this study } \\
\text { was limited to a specific } \\
\text { number } \\
\text { manufacturing } \\
\text { companies without } \\
\text { putting other sectors in } \\
\text { the economy into } \\
\text { consideration. }\end{array}$ \\
\hline 5 & $\begin{array}{l}\text { Abdurezzag, A., Khalid, } \\
\text { H., Musli. M., Md Fauzi. } \\
\text { A \& Aref. A (2016). } \\
\text { Relationship between } \\
\text { lean manufacturing and } \\
\text { business performance: } \\
\text { A conceptual model } \\
\text { based on Libyan } \\
\text { manufacturing } \\
\text { industries. }\end{array}$ & $\begin{array}{l}\text { This paper is to } \\
\text { propose } \\
\text { relationship model } \\
\text { between } \\
\text { manufacturing } \\
\text { practice and business } \\
\text { performance. Libyan } \\
\begin{array}{l}\text { industries who } \\
\text { implemented lean } \\
\text { manufacturing. }\end{array}\end{array}$ & $\begin{array}{l}\text { Structural } \\
\text { Equation Model } \\
\text { (SEM) was used. }\end{array}$ & $\begin{array}{l}\text { There are many tools of } \\
\text { lean manufacturing that } \\
\text { can be used in } \\
\text { The study shown that in } \\
\text { Libyan the industries } \\
\text { have several lean } \\
\text { manufacturing tools that } \\
\text { can be used to achieve } \\
\text { business performance. }\end{array}$ & $\begin{array}{l}\text { The study focused on } \\
\text { manufacturing } \\
\text { industries and ignores } \\
\text { the service industries. }\end{array}$ \\
\hline
\end{tabular}

\section{Challenges of Lean Management Application}

There are many challenges that organization are likely to encountered towards the adoption of lean management practice. Meanwhile, many organisations may have faced some challenges, which are likely to affects the adoption of LMP, such as, management issues, financial issues and governmental issues (Olatunji,2018) and also inadequate Power supply, poor transportation network and insecurity (Ogunro, 2014). These factors make every business environment unfriendly and unsafe for organisation to operate.

\section{Meta-Analysis of Lean Management Practice}

Table 3. shown the meta-Analysis on implementation of lean management,

\begin{tabular}{|c|c|c|c|c|c|}
\hline $\mathrm{S} / \mathrm{N}$ & AUTHORS & RESEARCH TOPIC & SAMPLE & RESULTS & CRITIQUE \\
\hline 1 & $\begin{array}{l}\text { Dinitris. F } \quad \& \\
\text { Theophilus. } \\
\text { (2011) }\end{array}$ & $\begin{array}{l}\text { Implementing lean } \\
\text { thinking paradigm } \\
\text { practices in medical set } \\
\text { up. }\end{array}$ & $\begin{array}{l}\text { Three (3) } \\
\text { hospitals }\end{array}$ & $\begin{array}{l}\text { Wall of departmentalization within } \\
\text { the service points that made the } \\
\text { customers not to be the center of } \\
\text { attraction rather the interest of } \\
\text { each units. }\end{array}$ & $\begin{array}{l}\text { Management staff of } \\
\text { medical needs to } \\
\text { understand the adoption } \\
\text { of lean management } \\
\text { thinking for their } \\
\text { improvement of patient } \\
\text { attention. }\end{array}$ \\
\hline 2 & $\begin{array}{l}\text { Eswaramoorth } \\
\text { i, M, } \\
\text { Kathiresan.G.R } \\
\text {., Prasad, P.S.S } \\
\text { \& } \\
\text { Mohanram.P.V } \\
\text {.(2011). }\end{array}$ & $\begin{array}{l}\text { A Survey on lean } \\
\text { practices in indian } \\
\text { machine tool industries. }\end{array}$ & $\begin{array}{l}29 \text { out of } 150 \\
\text { leading } \\
\text { machine tool } \\
\text { manufacturing } \\
\text { industries. }\end{array}$ & $\begin{array}{l}31.6 \% \text { of the companies have } \\
\text { implemented different lean tools } \\
\text { and techniques in selected areas } \\
\text { while } 68.4 \% \text { of the companies have } \\
\text { yet taken up lean initiatives. }\end{array}$ & $\begin{array}{l}\text { The study does not focus } \\
\text { on how to develop } \\
\text { proper training } \\
\text { demonstrator that can } \\
\text { teach employees lean } \\
\text { concept, in order to } \\
\text { become a lean thinker. }\end{array}$ \\
\hline 3 & $\begin{array}{l}\text { Keitany. P \& } \\
\text { Riwo-Abudho. } \\
\text { M (2014). }\end{array}$ & $\begin{array}{lr}\begin{array}{l}\text { Effects of } \\
\text { production }\end{array} & \text { lean } \\
\text { organizational } & \\
\text { performance: A case } \\
\text { study of } \\
\text { producing company in } \\
\text { Kenya. }\end{array}$ & $\begin{array}{l}40 \text { respondents } \\
\text { from a target } \\
\text { population of } \\
42 .\end{array}$ & $\begin{array}{l}\text { The management style and } \\
\text { coordinating of staff at all levels as } \\
\text { well will improve better inventory } \\
\text { management which might leads to } \\
\text { more efficient practice of lean } \\
\text { production. }\end{array}$ & $\begin{array}{l}\text { A single industry from } \\
\text { the entire industries of } \\
\text { flour producing } \\
\text { companies in the } \\
\text { country was used for the } \\
\text { research. }\end{array}$ \\
\hline 4 & $\begin{array}{l}\text { Onyeizugbe, C. } \\
\text { U \& Ike, F. O. } \\
(2016) .\end{array}$ & $\begin{array}{l}\text { Lean Production: A } \\
\text { Frontier for Improving } \\
\text { Performance of Oil and } \\
\text { Gas Companies in } \\
\text { Nigeria. }\end{array}$ & $\begin{array}{l}\text { Seventy-eight } \\
\text { (78) } \\
\text { respondents } \\
\text { out of } 167 \\
\text { workers in } 3 \\
\text { selected oil and } \\
\text { gas companies } \\
\text { from } 12 \text { oil and }\end{array}$ & $\begin{array}{l}\text { There is a significant positive } \\
\text { relationship between cellular } \\
\text { production and service delivery of } \\
\text { these companies. Moreso, lean } \\
\text { production can be used to resolve } \\
\text { severe organizational performance } \\
\text { problems in the oil and gas in } \\
\text { Rivers state of Nigeria. }\end{array}$ & $\begin{array}{lr}\text { This study } & \text { focused } \\
\text { mainly on } & \text { cellular } \\
\text { production } & \text { and } \\
\text { neglected } & \text { other } \\
\text { techniques of lean } \\
\text { production in oil and gas } \\
\text { industry. }\end{array}$ \\
\hline
\end{tabular}




\begin{tabular}{|c|c|c|c|c|c|}
\hline $\mathrm{S} / \mathrm{N}$ & AUTHORS & RESEARCH TOPIC & SAMPLE & RESULTS & CRITIQUE \\
\hline & & & $\begin{array}{l}\text { gas operating in } \\
\text { Rivers State. }\end{array}$ & & \\
\hline 5 & $\begin{array}{l}\text { Mohd. S } \\
\text { (2017) }\end{array}$ & $\begin{array}{l}\text { Implementation of lean } \\
\text { Manufacturing System } \\
\text { for Successful } \\
\text { Production System in } \\
\text { Manufacturing } \\
\text { Industries. }\end{array}$ & $\mathrm{N} / \mathrm{A}$ & $\begin{array}{l}\text { Successful implementation of lean } \\
\text { manufacturing is very important to } \\
\text { increase quality and waste } \\
\text { reduction. }\end{array}$ & $\begin{array}{l}\text { Though, the study } \\
\text { suggested } \\
\text { application of LM, but } \\
\text { fails to suggest the } \\
\text { implementation } \\
\text { techniques that maybe } \\
\text { adopted. }\end{array}$ \\
\hline 6 & $\begin{array}{l}\text { Onwughalu, } \\
\text { O.O., Okeke. } \\
\text { K.E \& Henry- } \\
\text { Chibor. E. } \\
\text { (2017) }\end{array}$ & $\begin{array}{l}\text { Lean Production and its } \\
\text { effect in Organisations: } \\
\text { A study of selected } \\
\text { manufacturing firms in } \\
\text { Nigeria. }\end{array}$ & $\begin{array}{l}10 \text { employees } \\
\text { from } 10 \\
\text { manufacturing } \\
\text { companies in } \\
\text { Port Harcourt, } \\
\text { Nigeria. }\end{array}$ & $\begin{array}{l}\text { Lean practices adoption had } \\
\text { significant relationship with } \\
\text { minimized variation associated } \\
\text { with suppliers, processing time and } \\
\text { demand. Thus, the study concluded } \\
\text { that LM principles and tools help to } \\
\text { achieve leanness in operations, } \\
\text { hence eliminating several forms of } \\
\text { wastes. }\end{array}$ & $\begin{array}{l}\text { Few sample sizes of ten } \\
(10) \text { respondents from } \\
10 \\
\text { manufacturing } \\
\text { companies. Hence, the } \\
\text { study was limited in } \\
\text { scope. }\end{array}$ \\
\hline
\end{tabular}

Source: Researcher (2020)

\section{Usefulness of the Lean Management (LM) Practice to Manufacturing and Service Organization.}

Chartered global management accountant (2015) opined that in the business competitive environment, organization is challenged to do more with fewer resources. Thus, the best way for all industries both manufacturing and non-manufacturing firms to increase work productivities, is to adopt lean management techniques. When Lean management practice is successfully implemented through effective planning and implementation the following outcome should be realized. These include: (i). Reduced lean time, (ii). Reduced work in progress, (iii). Improve flexibility, (iv). Reduced transaction, (v). Enhance communication, (vi). Reduce cost, (vii). Improve on-time deliveries, (viii). Increase sales, and (ix). it improves space utilization.

Openda (2013) posited that lean management concept has been refined and developed over the past decades in Japan. The reason being to improve quality and reduce cost to help Japanese businesses grow and become more competitive in world markets for selective production line.

\section{The way out}

In spite of the usefulness and challenges of practicing lean management in modern business organisations, its application will appear more appreciable, rewarding and useful to organizational success (minimizing cost, elimination of wastages, increase productivity, increase profitability and customers' satisfaction) if the following suggestions are considered:

1. Applying the principles of lean management as posit by Womack and Jones (1996) on page 8-9 of this work.

2. Lean management encompasses a set of practices, tools, techniques and methodologies that enable objectives of organisations to be met. When managers of organisations applied this method on product or service, it will help in eradicating all forms of wastages that does not have value or add value to their products or services. Apparently, managers will achieve its set objectives such as profitability and customers' satisfaction.

3. Lean management is applicable for all organisations whether manufacturing or service industries irrespective of their sizes. Although, this practice was developed in Japan to increase productivity and workflow of automobile industry, but due to it efficacy every other sector has adopted lean management practice in order to improve organisational performances.

4. Every organisations need to adopt lean management practice in order to stay alive in the new competitive market place. Specifically, LM is one of the modern techniques which organisations used to compete and survive in the global market. So, it is advisable that the application of lean management need to be properly used LM by managers of organisation in order to gives industry a competitive advantage edge over its rivals.

\section{Conclusion}

The practice of Lean management was introduced by Toyota Production System in Japan to improve business competitiveness by eradicating waste while increasing quality and customer satisfaction which include delivery time. Although, the LM practice is actually implemented only in the manufacturing firm, but literature has revealed that LM can be apply in other sectors. For every industry to gain competitive advantage and remain profitable, it is necessary to adopt lean management practice and thus improve customer satisfaction. Basically, lean management was implemented to reduce waste, inventory reduction, reduced lead time, less rework and financial savings of any industry that adopted the lean management practices. 


\section{Recommendations}

It is recommended to all organisations be it manufacturing or Services industries to adopt lean management practice in view of stiff global competition and increasing cost on the local environment. Specifically, industries across the globe need to adopt JIT, Jidoka and Heijunka principles has part of the leanest management tools which help organisation to eliminate wastes and improve organizational productivity.

More so, every organisation should know that theory of production focusing about lean transit to transformation of lean productivity. Therefore, all departments should understand their role in the lean production process.

\section{References}

1. Ajith, K. S., Singh, N. K., Shankar. R., \& Twari,M.K. (2008).Lean philosophy: Implementation in a forging company. Internatio nal Journal of Advanced Manufacturing Technology, 36, 451-462.

2. Alberto, P.S. (2014). Lean Implementation in service companies. Advances in Information and Communication Technology, 1(3), 1-10.

3. Alinaitwe, H. M. (2009). Prioritizinz lean construction barriers in Uganda' construction industry. Journal of construction in Developing countries, 11(1), 15-30.

4. Allway, M., \& Corbett, S. (2002). Shifting to lean service: stealing a page from manufacturers' playbooks, Journal of Organizational Excellence, 21(2),45-54.

5. Alsmadi, M., Almani, A., \& Jerisat, R. (2012). A comparative analysis of lean practices and performance in the UK manufacturing and service sector firm. Total Quality Management \& Business Excellence, 23 (4), 381-396.

6. Andres-Lopsez, E., Gonzalez, I, \& Sanz-Lobera, A. (2015). Lean service: Reassessment of lean manufacturing for service activities. Production Engineering, 132, 23-30.

7. Barraza, M, S., Smith, T., \& Dahlgaard-Park, S, M. (2009). Lean-Kaizen public service: an empirical approach in Spanish local governments, The TQM Journal,21(2), 143-167.

8. Bashir, A.M, Suresh. S, Oloke, D. A, Proverbs, D.G \&Gameson, R. (2015). Overcoming the challenges facing lean construction practice in the UK contracting organizations. International Journal of Architecture, Engineering and Construction. 4(1), 10-18.

9. Bayou, M, E., \& de Korvin, A. (2008). Measuring the leanness of manufacturing systems; a case study of Ford Motor company and general motors. Journal of Engineering and Technology Mgement, 25(4), 396-402.

10. Begam M.S, Swamnynathan. R \& Sekkizhar. J. (2013). Current trends on lean management-A review. International Journal of Lean Thinking, 4(2),15-21.

11. Bicheno, j. \& Holweg, M. (2009). The lean toolbox. The essential guide to lean transformation. Buckinham; Production and Inventory Control, Systems and Industrial Engineering Book.

12. Blikle. A. (2011). Doktryna Jakosci. Total Quality Management. www.firmyrodzinne.pl.

13. Chartered Global Management Accountant (2015). Lean management techniques. USA: Association of International Certified Professional Accountants. 1-17.

14. Burtonshaw-Gunn. S., Oluwaseun-Apo. D., Soriano-Meier.H., Garza-Reyes,J.A. \& Kumar.N. (2012).Adoption of lean manufacturing processes in developing companies: A case study of Gasland Nigeria limited. Conference Paper, www, researchgate.net/publication/283542418.

15. Christian F.F (2010). Lean mgt: Awareness, implementation status and need for implementation support in Virginia wood industry. Thesis.

16. Comm, C, L. (1998). Marketing Lean Initiatives in Service Industries. Journal of Professional Services Marketing, 18(7), 59-64.

17. Common, G., Johansen, E., \& Greenwood. D. (2000). A survey of the take up of lean concepts among UK construction companies. Proceedings of the $8^{\text {th }}$ Annual Conference of International Group for Lean construction. Brighton, UK.

18. Daferighe,E. E., James, E. O., \& Offiong, P. E. (2018). Lean accounting and waste management in brewery industry in Nigeria. Advances in Research, 15(1), 1-11.

19. David. A \& Federico, G, T. (2014). The value of lean in the service sector: A critique of theory \& practice. International Journal of Business nad Social Science, 5(2), 18-24.

20. Demeter. K., Chikan. A, \& Matyusz. Z. (2011). Labour productivity changes: Drivers, business impact and macroeconomic moderators. International Journal of Production Economics, 131(1), 215-223.

21. Dinitris. F \& Theophilus. F. (2011). Implementing lean thinking paradigm practices in medical set up. Business Management Dynamics, 1(2), 61-78.

22. Eswaramoorthi, G. R., Kathiresan, G.R., Prasad, P.S.S., \& Mohanran, P.V. (2011). A survey on lean practices in Indian machine tool industries. International Journal of Advanced Manufacturing Technology, 52(2), 1091-1101.

23. Fanny, Y.F (2014). The use $5 S$ in health care services. A literature reviews. International Journal of Business and Social Sciences, 5(10), 240-248.

24. Forrester, P., Shimizu, U., Soriano-Meier, H., Garza-Reyes, J, A., \& Basso, L. (2010). Lean production, market share and value creation in the agricultural machinery sector in Brazil. Journal of Manufacturing Technology Management, 21(7), 853-871.

25. Garza-Reyes, J. A., Oraifige, I., Soriano-Meter, H., Forrester, P. I. \& Harmanto, D. (2012). The development of a lean park homes production process using flow and simulation methods, Journal of Manufacturing Technology Management, 23 (2). $519-529$.

26. Gbedebo. M., Peter. F., \& Tiamiyu. M. (2018). Evaluation of value stream mapping application in pasta manufacturing: A case study of golden pasta company. American Journal of Engineering and Technology Management. 3(1), 1-22.

27. Graczkozwski. S. (2008). Total Quality Management Re-engineering: Lean management oraz ich rozwoj wobee global izacyjnych, longistyka.

28. Hillier, K. W., \& Clayton, B. R. (2016). Lean in service industries: A literature review. Conference series; Materials Sciences and Engineering, 149 (1), 1-10.

29. Hopp, W.J., \& Spearman, M.L. (2000) Factory physics: Foundations of Manufacturing Management, McGray- Hill,New York.

30. Hong, P., Ga (Mark) Yang, M. \& D. Dobrzykowski, D. (2014). Strategic customer service orientation, lean manufacturing practices and performance outcomes. Journal of Service Management, 25(5), 699-723.

31. Houshmands, M. \& Jamshidnezhadb. B. (2006). An extended model of design process of lean production systems by means of process variables robotics and computer-integrated manufacturing, 22 (1-16).

32. Hudson, M. (2007). Managing without Profit. The Art of Managing Third-section Organization. Directory of Social Change. London. @nd edition.

33. Jayaram. J., Ahire,S.L., \& Paul. D. (2010). Contingency relationships of firm size, TQM duration, unionization, and industry context in TQM implementation. A focus on total effects. Journal of Operations Management, 28(4), 345-356. 
34. Imam, S., Muhammad. Y., Hizkia, A. H \& Toto. R (2018). Design of Toyota production system based on heijunka principles to increase human work productivity. Saudi Journal of Engineering and Technology,2(3), 22-32.

35. Ioannis. B., Garza-Reyes, J. A. \& Kumar. V (2018). The impact of lean methods and tools on the operational performance of manufacturing organisations. International Journal of Production Research, 52(18).

36. Johnston, R. (1999). Sevice operations management, return to roots. International Journal of Operations \& Production Management, 19(2), 104-127.

37. Kehoe, K. (2007). Get lean in service, Yard \& Garden,Abi/inform complete, 15, 18-19

38. Keitany. P \& Riwo-Abudho. M (2014). Effects of lean production on organizational performance: A case study of flour producing company in Kenya. European Journal of Logistics Purchasing and Supply Chain Management, 2(2), 1-14.

39. Kocakulah, M. C., Brown, J. F., \& Thomson, J. W. (2008). Lean manufacturing principles and their application. Journal of Cost Management, 22(3), 16-27.

40. Koskela. L. (2000). An exploration towards a production theory and its application to construction. Doctotral dissertation. Helsinki University of Tectnology.

41. Kuhlang. P., Edtmayr. T., \& Sihn. W. (2011). Methodical approach to increase productivity and reduce lend time in assembly and production logistic process. Journal of Manufacturing Service and Technology, 4(1), 24-32.

42. Lawrence, J., \& Hottenstein, M. (1995). The relationship between JIT manufacturing and performance in Mexican plants affiliated with US companies. Journal of Operations Management, 13(1), 125-135.

43. Lichtarski, J. (1997). Podstawy nauki o przedsiebiorstwie, WAE., Wroclaw, s.224.

44. Liker, J. K., \& Meiner, D. P. (2008). Toyota Talent, MT Biznes, Warszawa.

45. Lukasz. D. (2012). The orijin and evolution of lean management system. Journal of International Studies, 5(1). 46-51.

46. Mahmut. T., Murat. A., Mehmet. E., Ozdul. K., \& Ertugrul. T (2019). An application of SMED and jidoka in lean production. . Journal of Manufacturing Service and Technology, 2(1), 1-12.

47. Maleyeff, J. (2006). Exploration of internal service systems using lean principles, management decision, 44(5), 674-689.

48. Manea. D. (2013). Lean production-concept. Review of General Management, 17(1), 164-171.

49. Masaaki. I. (2006). Gomba Kaizen, MT Bizness, Warszawa.

50. Mintz Testa, B. (2003). Lean Manufacturing-Processing operational lifesaver. Engineered Wood, btesta@hourstn.rr.com, 6 (1), 12-15.

51. Ming-Te, L., Kuo-Chung, M. A., \& Pan, W. T. (2013). Using data mining technique to perform the performance assessment of lean service. Neural Computing and Applications, 22(7-8), 1433-1445.

52. Mohd, S. (2017). Implementation of lean manufacturing system for successful production system in manufacturing industries. International Journal of Engineering Research and Application, 7(6), 41-46.

53. Mohd. H, Raneez. K \& Inamdar. H. (2010). Areas of lean manufacturing for productivity improvement unit. World Academic of Science, Engineering and Technology, 581-587.

54. Muhammad, O.A., Jouni. N. \& Markku. O (2013). Kanban in software development. A systematic literature review. Software Engine ering and Advanced Application. 9-16.

55. Nitin, U., Desmukh, S.G., \& Garg, S. (2010). Lean manufacturing systems for medium size manufacturing enterprises: International Journals of Management Science, 5(5), 362-375.

56. Ohno. T. (2008). System Produkcyjny Toyoty, prodpress.com Wroclaw.

57. Olatunji. O. (2018). Lean-in-Nigerian construction, State, barriers, strategies and go-to-gemba approach. Proceedings of the 16th Annual conference of the International Group for Lean Construction. Manchester, UK.

58. Omotayo. T\& Kulatunga. U (2017). Gemba kaizen modell based on BPMN for small and medium scale construction business in Nigeria. Htt://usir.salford.ac.uk/42753/

59. Omotayo. J. \& Udayangani. K. (2016). Achieving incremental cost reduction via kaizen costing in the Nigeria construction Indu stry. Tempere University of Technology, 3(2), 715-725

60. Onyeizugbe, C. U \& Ike, F. O. (2016). Lean Production: A Frontier for Improving Performance of Oil and Gas Companies in Nigeria. Journal of Business and Finance Management Research, 29(5), 35-41.

61. Onwughalu, O.O, Okeke, K. E \& Henry, C.E. (2017). Lean production and its effective in organisations: A study of selected manufacturing firms in Nigeria. Journal of Science Research and Essay, 6(4), 85-98.

62. Openda, C, K. (2013). Lean Manufacturing Practices and Performance of Organizations listed at the Nairobi Securities Exchange. Master of Business Administration, Thesis.

63. Piercy, $N \&$ Rich, N. (2009). Lean transformation in the pure service environment: the case of the call service centre. International Journal of Operations \& Production Management, 29(1), 54-76.

64. Rahman, S, Laosirihongthong, T. \& Sohal, A, S. (2010). Impact of lean strategy on operational performance: a study of Thai manufacturing companies. Journal of Manufacturing Technology Management, 21(7), 839-852.

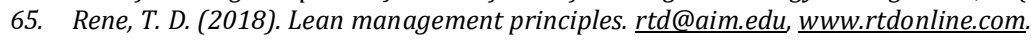

66. Ritchie, R., \& Angelis, J. (2009). Implementing lean into a service environment, advances in production management systems. New challenges, new approaches. Advances in Information and Communication Technology. 338, 587-594.

67. Ronach, S.S. (1998).'In search of productivity'. Harvard Business Review. September-October. 158.

68. Salem, O., Solomon, J., Genaidy, A., \& Luegring, M. (2005). Site implementation and assessment of lean construction techniques. Lean Construction Journals, 2(2), 1-21.

69. Sakakibara, S., Flynn, B. B., Schroeder, R. G. \& Morris, W. T. (1997). "The impact of just-in-time manufacturing and its infrastructure on manufacturing performance". Management Science, 43(9), 1246-1257.

70. Sarbjit, S.S. (2016). Lean Service. School of Economics and Business. Master's Thesis.

71. Saurah. T., \& Nishi. T. (2016). Lean manufacturing practices and firms performance measurement-A review paper. Httpt//www.researchgate.net/publication/308960626.

72. Seddon. J, \& O'Donovan, B. (2010). Rethinking lean service. Management Services, 54(1), 34-37.

73. Shah, R. \& Ward, P. (2003). Lean manufacturing context, practice, practice bundles and performance. Journal of Operations Management, 21(2), 129-149.

74. Shah. S, Ganji, E. N., \& Alec. C. (2017). Lean production practices to enhance organizational performance. EDP sciences, 1-7.

75. Singh, C.D., Rajdeem. S., Jaskamwal, S.M. \& Sukhvir. S (2013). Application of lean and JIT principles in supply chain management. International Journal of Management Research and Business sStrategy, 2(1), 84-99.

76. Soriano-Meier, H., \& Forrester, P. L. (2002). A model for evaluating the degree of leanness of manufacturing firms. Integrated Manufacturing Systems, 13(2), 104-109.

77. Staats, B, R., Brunner, D, J., \& Upton, D. M. (2011). Lean principles, learning, and knowledge work: Evidence from a software services provider. Journal of Operations Management, 29(5), 376-390.

78. Sugimori,Y., Kusunoki,K., Cho.F., \& Uchikawa, S. (1977). Toyota production system and Kanban system materialization of just-in-time and respect-for-human system. International Journal of Production Resources, 15(6), 553-564. 
79. Sundareshan, S. D., Swamy, T. S, \& Nanjundeswara, S,T (2015). A literature review on lean implementations: A comprehensive summary. International Journal of Engineering Research and Application, 5(1), 73-81.

80. Taj, S., \& Morosan, C. (2011). The impact of lean operations on the Chinese manufacturing performance. Journal of Manufacturing Technology Management, 22(2), 223-240.

81. Thangarajoo. Y., \& Smith. A. (2015). Lean Thinking: An overview. Industrial Engineering and Management, 4 (2), 1 -5.

82. Vignesh. $V$, Suresh. $M$ \& Aramvalarthan. S. (2016). Lean in service industries: A literature review. Materials Science and Engineering,14(1), 1-10.

83. Wael. A. (2017). Behavior of fibre reinforced concrete beams using recycled concrete coarse aggregate produced in qatar. College of Engineering Qatar University. 1-45.

84. Womack, J. P., \& Jones, D. T. (1996). Lean thinking: Banish waste and create wealth un your corporation. Journal of the Operational Reesearch Society, 1(1), 1-7.

85. Womack, J. P., \& Jones, D. T. (2008). Lean thinking szczuple, prodpress.com. Wroclaw, s.93.

86. Womack, J.P., Jones, D.T. \& Roos, D. (1990). The machine that change the world. Based on the Massachusetts Institute of Technology, 5Million Dollars 5- Year Study on the Future of the Automobile, New York: Rawson Associates.

87. Xue-Gang, S., \& Er-shi, Q. (2010). The application of lean thinking in transition of manufacturing services. International Conference on Multi Media and Information Technology, 48-51. 